\title{
Assessment of the matrix degenerative effects of MMP-3, ADAMTS-4, and HTRA1, injected into a bovine intervertebral disc organ culture model
}

\author{
Furtwängler, Tina ; Chan, Samantha C W ; Bahrenberg, Gregor ; Richards, Peter ; Gantenbein, \\ Benjamin
}

\begin{abstract}
STUDY DESIGN: In vitro study to develop an intervertebral disc degeneration organ culture model, using coccygeal bovine intervertebral discs (IVDs) and injection of proteolytic enzymes MMP-3, ADAMTS-4, and HTRA1. OBJECTIVE: This study aimed to develop an in vitro model of enzymemediated intervertebral disc degeneration to mimic the clinical outcome in humans for investigation of therapeutic treatment options. SUMMARY OF BACKGROUND DATA: Bovine IVDs are comparable with human IVDs in terms of cell composition and biomechanical behavior. Researchers injected papain and trypsin into them to create an intervertebral disc degeneration model with a degenerated nucleus pulposus (NP) area. They achieved macroscopic cavities as well as a loss of glycosaminoglycans (GAGs). However, none of these enzymes are clinically relevant. METHODS: Bovine IVDs were harvested maintaining the endplates. Active forms of MMP-3, ADAMTS-4, and HTRA1 were injected at a dose of 10 $\mathrm{g} / \mathrm{mL}$ each. Phosphate-buffered saline was injected as a control. Discs were cultured for 8 days and loaded diurnally (days 1-4 with $0.4 \mathrm{MPa}$ for $16 \mathrm{hr}$ ) and left under free swelling condition from days 4 to 8 to avoid expected artifacts because of dehydration of the NP. Outcome parameters included disc height, metabolic cell activity, DNA content, GAG content, total collagen content, relative gene expression, and histological investigation. RESULTS: The mean metabolic cell activity was significantly lower in the NP area of discs injected with ADAMTS-4 than the day 0 control discs. Disc height was decreased after injection with HTRA1 and was significantly correlated with changes in GAG/DNA of the NP tissue. Total collagen content tended to be lower in groups injected with ADAMTS4 and MMP-3. CONCLUSION: MMP-3, ADAMTS-4, and HTRA1 provoked neither visible matrix degradation nor major shifts in gene expression. However, cell activity was significantly reduced and HTRA1 induced loss of disc height that positively correlated with changes in GAG/DNA content. The use of higher doses of these enzymes or a combination thereof may, therefore, be necessary to induce disc degeneration.
\end{abstract}

DOI: https://doi.org/10.1097/BRS.0b013e31829ffde8

Posted at the Zurich Open Repository and Archive, University of Zurich

ZORA URL: https://doi.org/10.5167/uzh-85242

Journal Article

Accepted Version

Originally published at:

Furtwängler, Tina; Chan, Samantha C W; Bahrenberg, Gregor; Richards, Peter; Gantenbein, Benjamin (2013). Assessment of the matrix degenerative effects of MMP-3, ADAMTS-4, and HTRA1, injected into a bovine intervertebral disc organ culture model. Spine, 38(22):E1377-E1387.

DOI: https://doi.org/10.1097/BRS.0b013e31829ffde8 


\section{Assessment of the Matrix Degenerative Effects of}

MMP-3, ADAMTS-4 and HTRA1 injected into a

\section{bovine Intervertebral Disc Organ Culture Model}

Tina Furtwängler ${ }^{1}$, Samantha C.W. Chan ${ }^{1}$ PhD, Gregor Bahrenberg ${ }^{2,3}$,

Peter J. Richards ${ }^{2,3} \mathrm{PhD}$, Benjamin Gantenbein-Ritter ${ }^{1 *} \mathrm{PhD}$

${ }^{1}$ Institute for Surgical Technology and Biomechanics, University of Bern, Switzerland

${ }^{2}$ Bone and Stem Cell Research Group, Center for Applied Biotechnology and Molecular Medicine (CABMM), University of Zurich, Switzerland

${ }^{3}$ Zurich Center for Integrative Human Physiology (ZIHP), University of Zurich, Switzerland

*Corresponding Author

Benjamin Gantenbein-Ritter

University of Bern, Medical Faculty

Institute for Surgical Technology and Biomechanics

Tissue \& Organ Mechanobiology

Stauffacherstrasse 78

3014 Bern

Switzerland

Tel: + 410316315926

Fax: + 410316315960

E-mail: benjamin.gantenbein@istb.unibe.ch

Acknowledgements We thank Elena Calandriello for assistance with histological assays. 
1 Abstract

2 Study design. In vitro study to develop an intervertebral disc degeneration (IDD) organ

3 culture model, using coccygeal bovine intervertebral discs (IVDs) and injection of proteolytic

4 enzymes MMP-3, ADAMTS-4 and HTRA1.

5 Objective. This study aimed to develop an in-vitro model of enzyme-mediated IDD to mimic

6 the clinical outcome in humans for investigation of therapeutic treatment options.

7 Summary of Background Data. Bovine IVDs are comparable to human IVDs in terms of

8 cell composition and biomechanical behavior. Researchers injected papain and trypsin into

9 them to create an IDD model with a degenerated nucleus pulposus (NP) area. They achieved macroscopic cavities as well as a loss of glycosaminoglycans (GAGs). However, none of these enzymes are clinically relevant.

Methods. Bovine IVDs were harvested maintaining the endplates. Active forms of MMP-3, ADAMTS-4 and HTRA1 were injected at a dose of $10 \mu \mathrm{g} / \mathrm{ml}$ each. Phosphate buffered saline (PBS) was injected as a control. Discs were cultured for 8 days and loaded diurnally (day 1 to day 4 with $\sim 0.4 \mathrm{MPa}$ for $16 \mathrm{~h}$ ) and left under free swelling condition from day 4 to day 8 to avoid expected artifacts due to dehydration of the NP. Outcome parameters included disc height, metabolic cell activity, DNA content, glycosaminoglycan (GAG) content, total collagen content, relative gene expression and histological investigation.

Results. The mean metabolic cell activity was significantly lower in the NP area of discs injected with ADAMTS-4 compared to the day 0 control discs. Disc height was decreased following injection with HTRA1, and was significantly correlated with changes in GAG/DNA of the NP tissue. Total collagen content tended to be lower in groups injected with 
1 Conclusions. MMP-3, ADAMTS-4 and HTRA1 neither provoked visible matrix degradation

2 nor major shifts in gene expression. However, cell activity was significantly reduced and

3 HTRA1 induced loss of disc height which positively correlated with changes in GAG/DNA

4 content. The use of higher doses of these enzymes or a combination thereof may therefore be

5 necessary to induce disc degeneration. 


\section{Keypoints}

2

- Injection of ADAMTS-4 resulted in significantly reduced metabolic cell activity in the $\mathrm{NP}$ area after 8 days of diurnally loaded organ culture compared to the day 0 control group $(\mathrm{p}=0.0433)$.

- The change in disc height due to HTRA1injection positively correlated with the change in GAG/DNA of the NP tissue $\left(\mathrm{r}_{\text {spearman }}=1.0, p=0.0167\right)$.

- Total collagen content measured indirectly by hydroxy (HO)-proline content was not significantly reduced but tended to be lower in groups injected with ADAMTS-4 and MMP-3.

- GAG/ HO ratio was generally higher in NP (11.32 \pm 2.30 , PBS control) and lower in AF tissue $(3.45 \pm 0.63)$. No significant changes were found among treatment groups.

- Relative gene expression of anabolic and catabolic genes did not show any significant changes after 8 days of organ culture.

- Histology of sagittal sections revealed no significant reductions in proteoglycan content nor collagen content (Masson trichrome, picrosirius red, safranin o/fast green staining) 


\section{Miniabstract}

2 Three enzymes, MMP-3, ADAMTS-4 and HTRA1 were injected into bovine in vitro organ

3 culture for 8 days. Metabolic cell activity was significantly reduced in discs injected with

4 ADAMTS-4. No significant changes were observed in tissue gene expression, collagen 5 content or morphology although HTRA1 did induce a loss in disc height which positively 6 correlated with changes in GAG/DNA content. 


\section{Introduction}

2 Low back pain (LBP), a common musculoskeletal disorder ${ }^{1-3}$ with a lifetime-prevalence of up 3 to $84 \%^{4}$ causes an enormous economic burden due to activity limitation and work absence. ${ }^{5}$

4 Lumbar intervertebral disc degeneration (IDD) is highly associated with non-specific LBP. ${ }^{6}$ It

5 is a multi-causal condition due to aging, ${ }^{7,8}$ genetic components, ${ }^{9-11}$ obesity ${ }^{12}$ and carrying out

6 identical work or posture almost all day. ${ }^{13}$ Biomechanical studies showed that complex 7 loading like asymmetric compression of the intervertebral disc (IVD) has detrimental 8 effects. ${ }^{14,15}$ One major characteristic of IDD is a predominance of catabolic enzymes over the 9 main anabolic components, namely type-II collagen and aggrecan. The proteolytic endopeptidase MMP-3 could be found to induce loss of proteoglycans (PGs) in the aging IVD of mice. ${ }^{16}$ Higher levels of MMP-3 were found in human degenerated discs, which suggested that MMP-3 may be involved in IDD. ${ }^{17}$ ADAMTS-4, a metalloproteinase, which cleaves aggrecan, ${ }^{18}$ is expressed in herniated disc regions, accompanied with a decrease in PGs. ${ }^{19}$ Higher degeneration levels could be correlated with higher amount of ADAMTS-4 in NP and $\mathrm{AF}^{20}$ thus, it plays a major role in IDD. ${ }^{21}$ Furthermore, mRNA and protein levels of the serine proteinase HTRA1 were shown to be elevated in patients with severe IDD. ${ }^{22}$ It provoked a significant increase in MMP-1,-3, -13 and ADAMTS-4 and a decrease in aggrecan.

Current treatment options for IDD in the field of tissue engineering aim to repair or to regenerate the NP by injecting biomaterials ${ }^{23,24}$ seeded with cells ${ }^{25}$ and preconditioned with growth-factors. ${ }^{26,27}$ Before testing them in vivo it is necessary to test them in vitro in an animal organ culture model that exhibits similar cell types, extracellular matrix (ECM) components, biochemical and biomechanical behavior and a degenerated NP area that allows injection of some biomaterial combined with an intact AF. Existing models of IDD using bovine explants generate cavities by injection of papain and trypsin. ${ }^{28-30}$ However, these previously tested enzymes are very general proteases and cleave multiple peptide bindings 
1 and are not very specific to the problem of human IDD. Thus, there is a general lack of

2 knowledge whether more clinical relevant enzymes, such as ADAMTS-4, MMP-3 or HTRA1

3 would cause a degenerative pattern to a disc tissue if injected into a healthy IVD.

4 The aim of this study was to develop an animal organ culture model of enzyme-driven

5 intervertebral disc degeneration that can be used to mimic the clinical outcome of human

6 IDD. Studies were carried out to determine the effects of a single injection of MMP-3,

7 ADAMTS-4 or HTRA1, in bovine coccygeal IVDs cultured for 8 days under diurnal loading.

8 Typical features of IDD observed in this system included decreases in metabolic cell activity,

9 DNA, glycosaminoglycans (GAG) and collagen content as well as an up-regulation in the expression of endogenous catabolic genes and a down-regulation in the expression of anabolic genes.

\section{Materials and Methods}

Disc harvest and injection of selected enzymes. The preparation of intact IVD for organ culture followed our previously established protocol. ${ }^{31}$ Fresh bovine tails aged between 6 and 9 months obtained from a local abattoir were dissected within 4 hours after slaughter. Five to six coccygeal bovine IVDs could be harvested per tail. Muscles and tendons were removed and the IVD was cut 1-2 mm towards the vertebra by hammering on top using a custom-made industrial blade holder. Hyaline cartilage of the growth plate on the cutting side was removed until only the bony endplate was exposed. Discs were washed with a jet lavage system (Zimmer inc., Münsingen, Switzerland) with sterile lactated Ringer's solution for 30 seconds on each site and an angle of about $60^{\circ}$ to allow better diffusion. ${ }^{32}$ In four discs either active enzymes or phosphate buffered saline (PBS) as a control has been injected using a $1 \mathrm{ml}$ syringe (BD Luer Lock TM, Franklin Lakes NJ, USA) with a sterile 22-G needle. For MMP-3 (SRP7783, Sigma-Aldrich, Buchs, Switzerland) injections a Hamilton syringe (\#1710, 100ml 
1 volume; Hamilton, Bonaduz, Switzerland) was used. The aim was to inject as much volume

2 as possible to compensate for the differences in disc size. The most distal IVD with the

3 smallest diameter was used as day 0 control. The enzyme concentrations used were chosen

4 based on the following findings from other researchers. Ishiguro et al. detected a MMP-3

5 concentration of $11.7 \mu \mathrm{g} / \mathrm{ml}$ in the synovial fluid of osteoarthritis patients. ${ }^{33} \mathrm{~A}$ plasma 6 concentration of ADAMTS-4 of $100.2 \pm 31.6 \mathrm{ng} / \mathrm{ml}$ could be found in patients with acute 7 coronary syndrome. ${ }^{34}$ Tiaden et al. incubated human IVD cells from herniated IVDs for $24 \mathrm{~h}$ 8 in medium supplemented with recombinant HTRA1 at a concentration of $5 \mu \mathrm{g} / \mathrm{ml}$ to 9 investigate the role of HTRA1 in IVD degeneration. ${ }^{22}$ Purified recombinant active HTRA1 (HTRA1 $\Delta \mathrm{mac})$ was produced in Escherichia coli and purified using metal-affinity chromatography as previously described.$^{35}$ There were five repeats run $(\mathrm{N}=5)$, each with a freshly harvested bovine tail and the following group assignment for every tail: Group 1:

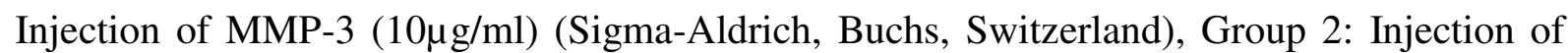

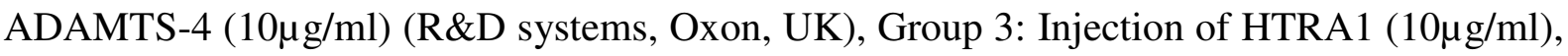
Group 4: Injection of PBS (Control), Group 5: day 0 fresh Control.

Organ culture, loading equipment and loading regime. The injected discs were placed in culture chambers, which were specifically designed for a novel type of two degree of freedom bioreactor. ${ }^{32}$ The chambers consisted of two cylindrical glass parts, the upper one enclosing the lower one. They are tightly connected to blocks made of polyoxymethylene which carry serrated titanium plates that are in direct contact with the discs. The chambers were fixed with a bar construction and filled with High Glucose Dulbecco's Modified Eagle Medium (HGDMEM) (Gibco, Invitrogen, Basel, Switzerland) containing 4.5 g/l D-glucose, L-Glutamin, $0.11 \mathrm{~g} / \mathrm{l}$ pyruvate, $100 \mathrm{U} / \mathrm{ml}$ streptomycin and $100 \mu \mathrm{g} / \mathrm{ml}$ penicillin, $5 \%$ fetal calf serum (FCS) and $0.1 \%$ amphotericin $\beta$ (all from Sigma-Aldrich, Buchs, Switzerland). The chambers were 
1 placed in the incubator at $37^{\circ} \mathrm{C}$ and $5 \% \mathrm{CO}_{2}$. Medium was replaced every two days. For the

2 first $24 \mathrm{~h}$, the discs were not loaded to avoid pressing out the enzyme after injection. From

3 day 1 to day 4 three diurnally loading cycles (with $\sim 0.4 \mathrm{MPa}$ for $16 \mathrm{~h}$ and no load for $8 \mathrm{~h}$ ) have

4 been applied. For loading plastic boxes filled with lead beads and a total weight of $4 \mathrm{~kg}$ have

5 been used. No load has been applied the remaining four cycles until day 8 to avoid expected

6 artifacts due to dehydration of the NP. The aim was to detect only the effects of enzyme 7 injection.

9 Disc height. The disc height was measured using an analogue caliper, which has been placed along the midline of the disc for measurement.

Metabolic cell activity. Metabolic cell activity was measured using the resazurin sodium salt metabolic cell activity assay (Sigma-Aldrich, Buchs, Switzerland). NP and AF tissue of all experimental groups were incubated in $500 \mu$ l of resazurin solution $(50 \mu \mathrm{M}$ in HG-DMEM containing 5\%FCS) for 5 hours at $37^{\circ} \mathrm{C}$. Fluorescence was measured at an excitation wavelength of $547 \mathrm{~nm}$ and emission wavelength of 582nm using a spectramax M5 microplate reader (Molecular Devices, Sunnyvale, United States).

Determination of GAG, DNA and Hydroxy (HO)-Proline content. Dried tissue samples were digested for approximately 16 hours at $60^{\circ} \mathrm{C}$ using $125 \mu \mathrm{g} / \mathrm{ml}$ papain from Papaya latex (Sigma-Aldrich, Buchs, Switzerland). For GAG content determination 1,9 dimethylmethylene blue (DMMB) at $\mathrm{pH} 1.5$ and chondroitin sulfate (Sigma-Aldrich) for the standard curve has been used. Absorbance was measured at $595 \mathrm{~nm}$ immediately. The quantity of DNA was determined using Bisbenzimide (Hoechst 33258 dye). Standards were prepared from calf 
1 thymus (Sigma-Aldrich). The plate was read at excitation wavelength of $350 \mathrm{~nm}$ and emission

2 wavelength of $450 \mathrm{~nm}$.

3 For determination of HO-proline a colorimetric quantitative assay was used. Color reaction

4 and standards were prepared in duplicates using saturated $\mathrm{NaCl}$, Chloramin $\mathrm{T}$ (Sigma5 Aldrich) and 4-Dimethylamino-benzaldehyd (DABA) solution (Fluka, Sigma-Aldrich, 6 Switzerland). Absorbance was read at 560nm. All assays were read using a spectramax M5 7 microplate reader (Molecular Devices, Sunnyvale, United States).

8

Real-time polymerase chain reaction (PCR). NP and AF tissue was pulverized under liquid nitrogen and total RNA was isolated using TRI REAGENT®) (Molecular Research Center, Cincinnati, MA, USA), GenElute miniprep kit (Sigma-Aldrich, Buchs, Switzerland) and DNase I (Sigma-Aldrich). To synthesize cDNA by reverse transcription the iScript kit from Bio-Rad was used. cDNA was diluted with $80 \mu 1$ of $1 \mathrm{X}$ tris-ethylenediaminetetraacetic acid (EDTA)-buffer. A mastermix containing forward and reverse primers of the bovine species of selected anabolic and catabolic genes and $\mathrm{iQ}^{\mathrm{TM}} \mathrm{SYBR}^{\circledR}$ Green Supermix (Bio-Rad, Cressier, Switzerland) was used. Real-time PCR was conducted on a real-time PCR detection system (iQ5 cycler, Bio-Rad) using the following amplification routine: denaturation $95^{\circ} \mathrm{C}$ for $3 \mathrm{~min}$, 50 amplification cycles: $95^{\circ} \mathrm{C}$ for $10 \mathrm{~s}, 57^{\circ} \mathrm{C}$ for $40 \mathrm{~s}$, followed by melting curve analysis. As reference ribosomal $18 \mathrm{~S}$ has been used. Oligonucleotide primers (all from Microsynth, Balgach, $\mathrm{CH}$ ) have been designed with Primer Beacon Designer ${ }^{\mathrm{TM}}$ Software (Premier Biosoft Inc., Palo Alto, CA, USA) using nucleotide sequences taken from the GenBank database. The primers are listed in Table 1. The cycle number at which increase in fluorescence and therefore in cDNA appears exponential was measured by setting the threshold to 55 relative fluorescence units (RFUs). The relative gene expression $\left(2^{-\Delta \Delta C t}\right)$ was determined by comparing either $\Delta \mathrm{C}_{\mathrm{t}}$ of day 0 samples with $\Delta \mathrm{C}_{\mathrm{t}}$ of the enzyme injected discs of day 8 . 
1

2 Histological evaluation. Discs cut into halves were fixed in $4 \%$ formalin for 2 days. Samples

3 were dehydrated and infiltrated and finally embedded in methyl methacrylate (MMA).

4 Samples were sectioned into slides of $6 \mu \mathrm{m}$ thickness using a microtome (Microm

5 International, Waldorf, Germany). Slides were stained with Masson's Trichrome stain ${ }^{36}$,

6 Safranin $\mathrm{O} /$ Fast green and picrosirius stain. The stained slides were mounted in Eukitt ${ }^{\mathrm{TM}}$

7 (Sigma) and photographed using the bright field modus of the Nikon Eclipse 800 microscope.

8

9 Statistics. Mean values \pm the standard error of the mean (SEM) were calculated. Prism 6, 10 11

GraphPad Software, Inc., v6.0b has been used for statistical analysis. For statistical analysis, the non-parametric Kruskal-Wallis-test was used and Dunn's test for post-hoc pairwise comparisons. Spearman's rank correlation coefficient was used to compare changes in disk height and GAG/DNA content. A significance value of $p<0.05$ was specified.

\section{Results}

\section{Disc height versus GAG content}

The change in disc height due to HTRA1injection positively correlated with the change in GAG/DNA of the NP tissue $\left(\mathrm{r}_{\text {spearman }}=1.0, p=0.0167\right.$, Figure 1$)$. These results suggest that HTRA1 may contribute to decreases in disc height under pathological conditions and may subsequently provoke additional features of IDD.

Metabolic cell activity. Metabolic cell activity was expressed as relative fluorescent units (RFUs) and normalized to the dry weight of the tissue. A significantly lower metabolic cell activity was observed in the ADAMTS-4 injected group as compared to the Control group at 
1 day 0 ( $p=0.0433$, Figure 2). ADAMTS-4 was therefore assumed to be a suitable enzyme to

2 mimic IDD in the described experimental setup. In general, metabolic cell activity was higher

3 for day 0 samples than for day 8 samples (Figure 2). This difference was also statistically

4 significant in the AF for the pairing of MMP-3 versus d0 $(p=0.0079)$ and HTRA1 versus d0 $5 \quad(p=0.0394)$.

7 DNA, GAG and HO-Proline content. The mean DNA content in the NP tissue was higher 8 for the day 0 group than the four groups cultured for 8 days (Figure 3). Discs injected with

9 HTRA1 and the PBS Control group showed the lowest values, although were not significantly reduced. The values in AF tissue were similar in all groups. None of the groups showed significantly different DNA content. The mean change in GAG content normalized to DNA is shown in Figure 4. The mean GAG content tended to be higher after culture in NP tissue in all groups. The values for NP tissue were highest for the PBS control, followed by HTRA1, ADAMTS-4 and MMP-3. The HO-proline content tended to be decreased in ADAMTS-4 and MMP-3 (Figure 5). However, no significant differences were attained between treatment groups, also with respect to GAG/HO-Proline ratio (Figure 6).

Relative gene expression. Comparison of groups injected with enzymes to the PBS control group revealed a higher expression of anabolic genes, i.e. ACAN and type-II collagen in the $\mathrm{NP}$ and AF of enzyme-injected discs (Figure 7). Interestingly, gene expression of the two catabolic enzymes ADAMTS-4 and MMP-13 was found to be up-regulated by about 10,000 times in the NP and these were found down-regulated in the annulus fibrosus tissue relative to PBS control. Expression levels of RNA of inhibitors of metalloproteinases, TIMP-1 and TIMP-3 remained unchanged from level of the PBS control and day 0 control (day 0 data not shown). MMP-3 did not show major deviations from the baseline (Figure 7). 
1

2 Histological evaluation. No striking differences in stained components could be observed in 3 any of the cultured samples at day 0 to day 8 (Figure 8). Injection of ECM degenerating 4 enzymes did not lead to the expected pattern of disc degeneration, and did not induce any 5 major structural changes at the cellular level (data not shown). However, a decrease in 6 proteoglycans was noted in the nucleus pulposus area following treatment with ADAMTS-4 7 (Figure 8).

\section{Discussion}

\section{IVD Organ Culture Study}

The aim of this study was to develop an in vitro bovine organ culture model of IDD by injecting a subset of catabolic proteases with the intention of mimicking the clinical outcome of human IDD. Here, we focused on three selected enzymes representing two out of four major classes of proteases, i.e. MMP-3, ADAMTS-4 (both belonging to the family of MMPs) and HTRA1 (a representative of the serine proteases, Figure 9). ${ }^{37}$

Decrease of disc height due to a loss in GAG content is a typical feature of IDD. ${ }^{38,39}$ In this study, the change in disc height of the group injected with HTRA1 in fact showed positive correlation to the change in GAG content, which leads to the assumption that HTRA1 could have degenerative potential, which is supported by previous findings from studies carried out by the authors where HTRA1 was demonstrated as being upregulated in degenerated IVDs from human patients. ${ }^{22}$.

The effect of external loading is an important feature of the study design to consider. The human IVD is exposed to certain loads, such as static or dynamic axial compression and torsion. Complex loading, for example bending combined with compression, as well as overload or immobilization ${ }^{40}$ can result in disc damage. However, there is a physiological 
1 load ranging from $0.1 \mathrm{MPa}$ to $\sim 2 \mathrm{MPa}^{41}$ in which dynamic compression facilitates nutrition

2 and waste exchange. ${ }^{42}$ This means that IVDs require a certain physiological amount of load

3 both in vivo and in vitro. The load of $0.4 \mathrm{MPa}$ applied diurnally for three cycles in this study

4 is comparable to the load applied in other studies but is still far from the range that is thought

5 to cause degeneration. A study which investigated the influence of targeted trypsin injection

6 and 16 hours compression loading on magnetic resonance (MR) parameters, mechanical and

7 biomechanical parameters of bovine disc segment showed that only loading had a significant

8 effect on the MR parameters and biochemical composition in terms of IDD whereas trypsin

9 had a larger effect on the mechanical properties. ${ }^{43}$ However, the detrimental role of the loading pattern should be investigated in further studies.

In the current study, the metabolic cell activity in NP tissue was significantly lower in discs injected with ADAMTS-4 compared to d0 control. This result suggested that injection of ADAMTS-4 at a concentration of $10 \mu \mathrm{g} / \mathrm{ml}$ may lower the cell proliferation and viability in the described experimental setup and therefore may represent a suitable tool for an in vitro animal IDD model. Certainly, reduced cell viability has previously been reported in whole bovine or rabbit IVD organ cultures cultured under degenerative conditions. ${ }^{44-46}$ The bovine coccygeal IVD is considered to be the most appropriate tissue to mimic the conditions in the human IVD and as such, has been used several times for characterization and investigation of an organ culture model. ${ }^{45,47-52}$ However, studies that focus on simulation of IDD using bovine discs are rare. To the authors' knowledge, the present study is the first to use injections of recombinant human MMP-3, ADAMTS-4 and HTRA1 to develop an enzyme-based disc degeneration model using the bovine IVD. The current study can be compared with other organ culture models using more catabolic proteolytic enzymes like papain and trypsin. Several studies using those enzymes either with or without load revealed more explicit results in terms of detection of macroscopic cavities after injection. Compressive mechanical loading 
1 even accelerated loss of proteoglycans, water content and mechanical properties in much

2 shorter incubation times (around 24-48h). ${ }^{28,43,53}$ A short overview of current studies using

3 trypsin and/or papain (a cysteine protease, Figure 9) to simulate IDD is given in Table 2.

$4 \quad$ Trypsin and papain being non-specific in terms of peptide recognition sites and also being 5 responsible for major GAG loss over a short period of time, however, does not attack cell 6 viability of remaining cells, ${ }^{29,53}$ which is surprising but also interesting for the application of 7 testing hydrogels for the IVD repair. ${ }^{30}$ Comparing papain with trypsin, trypsin has to be 8 considered less standardized since it represents a mixture of at least three trypsins and thus, is

9 difficult to dose or compare between different products and batches. Furthermore, comparing

the macroscopic changes of the investigated three clinically relevant enzymes with the cysteine-dependent proteinase papain there was no real cavity visible using sagittal cuts. Thus, papain produces a highly consistent and reproducible space for injection of biomaterials and seems to act specifically on GAG-rich tissue (Figure 10). ${ }^{28,29}$

\section{Molecular structure and catabolic actions of the three investigated enzymes}

MMPs are endopeptidases that play an essential role in various physiological and pathological processes such as angiogenesis, morphogenesis, ${ }^{54}$ tissue repair, tumor metastasis, tumor invasion, and inflammatory diseases. MMPs are a family of zinc-containing and zinc dependent enzymes that have the ability to breakdown connective tissue by hydrolyzing components of the ECM. ${ }^{55}$ This is important in the process of tissue resorption and the release of biologically active molecules. Most of the MMPs are composed of a propeptide domain that contains a cysteine switch motif with a sulfhydryl group, ${ }^{56}$ a catalytic domain, which contains three conserved histidines, which ligate the active site $\mathrm{Zn}^{2+}$, a proline-rich linker region and a hemopexin-like C-terminal domain (Figure 9). Most MMPs are secreted as inactive pro-enzymes (zymogens). The cysteine thiol and zinc ion interaction keeps proMMPs 
1 in a latent state. This linkage must be disrupted to activate the enzyme. ${ }^{57}$ The exact in vivo

2 mechanism of activation of proMMPs is not yet known. Further, all MMPs (except MMP-23)

3 have a signal peptide to function in the extracellular space. ${ }^{58}$ In our, study we made sure that

4 all enzymes were already in the activated state as we obtained them from the manufacturers to

5 exclude uncertainty from activation procedure using mercury-containing compounds, such as

6 4-Amino-Phenyl-Mercuric Acetate (APMA).

7 The ADAMTS (A disintegrin and metalloproteinase with thrombospondin motifs) family 8 belongs to the superfamily of metalloproteinases and includes 19 members. ADAMTS-4 9 (synonym aggrecanase-1) is a secreted multidomain metalloproteinase (Figure 9), ${ }^{59}$ which cleaves aggrecan at four sites within the chondroitin-sulfate rich region of the aggrecan core protein. The prodomain is essential for proper folding. It impedes substrate access by its proximity to the catalytic pocket and its excision is a prerequisite for ADAMTS-4 activity (Figure 9). ${ }^{60}$ The catalytic domain contains the active site, the catalytic zinc essential for hydrolysis and two calcium-binding sites. The active site has a dynamic nature with two different conformations depending on the presence of a ligand. Concerning the disintegrinlike domain (Dis) up to now there is no evidence that it binds integrin but very likely it also regulates the enzyme activity. The ancillary domains are the central thrombospondin domain (TS), the cysteine-rich domain (CysR) and the spacer domain (Figure 9) ${ }^{60}$

In humans, the high temperature requirement (HTRA) serine protease family consists of four members termed HTRA1, $-2,-3$ and $-4 .{ }^{61}$ In addition to its involvement in tumor suppression, HTRA1 may also play a role in cartilage, joint and IVD degeneration due to its ability to upregulate MMP expression through the generation of fibronectin fragments. ${ }^{22,62}$ It has also been speculated that HTRA1 may influence the development and maintenance of other musculoskeletal tissues including muscle and bone. ${ }^{63,64}$ 
1

\section{Inhibition of MMPs}

2 The catalytic activity of MMPs is regulated at four points: First, at the level of transcription

3 and thus the gene expression. Secondly, growth factors and cytokines play a role. It could be

4 shown that TNF- $\alpha$ and to an even higher extend IL-1 $\beta$ up-regulates MMP-3, -9 and $-13 .{ }^{65}$ The

5 third point for regulation is the pro-enzyme activation through the interaction with ECM

6 components. $^{54}$ In vivo they are activated by tissue or plasma proteinases. In vitro e.g. 7 mercurial compounds such as APMA) are used to activate the enzymes. A fourth aspect is the 8 inactivation of enzymes, which means inhibition by endogenous inhibitors. Such inhibitors 9 are called Tissue Inhibitors of Metalloproteinases (TIMPs). There are currently four known

TIMPs (TIMP-1, TIMP-2, TIMP-3 and TIMP-4) in humans, which bind tightly to the catalytic side of most metalloproteinases in a 1:1 stoichiometry. TIMP-1 and TIMP-2 are able to inhibit all MMPs. In particular, TIMP-1 forms a complex with the catalytic domain of MMP-3. However, the gene expression level of our study indicated no change during the culture time fort he TIMPs but a strong upregulation of mRNA of MMP-13 and ADAMTS-4 (Figure 7).

\section{Doses of enzymes detected in human pathological state}

Which doses of exogenous enzymes are meaningful to induce disc degeneration in an organ culture model? Here, we relied on evidence of osteoarthritic research. Examples for the concentration of MMP-3 in the blood serum level of patients suffering from anti-neutrophil cytoplasmic antibodies-associated vasculitis or oral lichen planus ranged from 21.6 to 99.6 ng/ml. The secreted MMP-3 level in the supernatants from IVD cells treated with HTRA1 was even lower. Nevertheless, later MMP-3 concentration selection based on the findings of Nemoto et al. ${ }^{17}$ who found concentrations of $0.57 \mu \mathrm{g} / \mathrm{ml} / \mathrm{mg}$ wet weight MMP-3 released in the medium of human IVD explant culture and Ishiguro et $a l .{ }^{33}$ detected concentration of 11.7 
$1 \mu \mathrm{g} / \mathrm{ml}$ in synovial fluid of osteoarthritic patients. Only very few information could be found

2 on typical concentrations of ADAMTS-4. From patients with acute coronary syndrome a

3 concentration of $100.2 \mathrm{ng} / \mathrm{ml} \pm 31.6$ ADAMTS- 4 was measured in the plasma. ${ }^{34}$ The decision

4 for the final test concentration of HTRA1 was mainly based on the work of Tiaden et al. ${ }^{22}$

5 who incubated human IVD cells from herniated IVDs for 24 hours in medium supplemented

6 with recombinant HTRA1 at a concentration of $5 \mu \mathrm{g} / \mathrm{ml}$ to investigate the role of HTRA1 in

7 IVD degeneration. The results described herein, lead to the conclusion that none of the

8 investigated enzymes at this dosage, are capable of inducing profound changes in the disc

9 ECM. Consequently, we may have to consider increased doses, and/or combinations of these

selected enzymes in future studies. However, we also injected a $100 \mu \mathrm{g}$ of HTRA1 ( 1001,000 times more than physiologically measured in synovial fluid) under free-swelling to exclude artifacts from loading. However, even with this high concentration and in the absence of loading, we could not detect any striking changes happening to the ECM (data not shown).

\section{Conclusion}

It was the aim of this study to assess the degenerative effects of matrix degrading enzymes but also to comprise their clinical relevance. Although, clinical relevant MMP-3, ADAMTS-4 and HTRA1 showed some promising effects, the use of higher doses of these enzymes or a combination thereof may be necessary to induce disc degeneration. Considering the balance between costs per unit or per $\mu \mathrm{g}$ of enzyme, it is a consequence that the proteinases papain or trypsin are much more catabolic (Figure 10) and much cheaper per i.U. cysteine. Therefore, higher concentrations of papain and trypsin can be applied easily for a disc degeneration model and make them more appealing than the injection of excess MMP-3, ADAMTS-4 or HTRA1 although not mimicking the clinical situation. 


\section{References}

2 1. Ricci JA, Stewart WF, Chee E, et al. Back pain exacerbations and lost productive time

3 costs in United States workers. Spine (Phila Pa 1976) 2006; 31:3052-60.

2. Stewart WF, Ricci JA, Chee E, et al. Lost productive time and costs due to diabetes and diabetic neuropathic pain in the US workforce. J Occup Environ Med 2007; 49:672-9.

3. Strine TW, Hootman JM. US national prevalence and correlates of low back and neck pain among adults. Arthritis Rheum 2007; 57:656-65.

4. Cassidy JD, Carroll LJ, Côté P. The Saskatchewan health and back pain survey. The prevalence of low back pain and related disability in Saskatchewan adults. Spine (Phila Pa 1976) 1998; 23:1860-6; discussion 1867.

5. Maniadakis N, Gray A. The economic burden of back pain in the UK. Pain 2000; 84:95103.

6. Livshits G, Popham M, Malkin I, et al. Lumbar disc degeneration and genetic factors are the main risk factors for low back pain in women: the UK Twin Spine Study. Ann Rheum Dis 2011; 70:1740-5.

7. Boos N, Weissbach S, Rohrbach H, et al. Classification of age-related changes in lumbar intervertebral discs: 2002 Volvo Award in basic science. Spine (Phila Pa 1976) 2002; 27:2631-44.

8. Miller JA, Schmatz C, Schultz AB. Lumbar disc degeneration: correlation with age, sex, and spine level in 600 autopsy specimens Spine 1988; 13:173-178.

9. Battié MC, Videman T, Gibbons LE, et al. 1995 Volvo Award in clinical sciences. Determinants of lumbar disc degeneration. A study relating lifetime exposures and magnetic resonance imaging findings in identical twins. Spine (Phila Pa 1976) 1995; 20:2601-12. 
1 10. Kalichman L, Hunter DJ. The genetics of intervertebral disc degeneration. Associated

$2 \quad$ genes. Joint Bone Spine 2008; 75:388-96.

3 11. Battié MC, Videman T, Levalahti E, et al. Heritability of low back pain and the role of $4 \quad$ disc degeneration. Pain 2007; 131:272-80.

5 12. Biglarian A, Seifi B, Bakhshi E, et al. Low back pain prevalence and associated factors in 6 Iranian population: findings from the national health survey. Pain Res Treat 2012; $7 \quad 2012: 653060$.

13. Li JY, Wang S, He LH, et al. Risk factors of low back pain among the Chinese occupational population: a case-control study. Biomed Environ Sci 2012; 25:421-9.

14. Walter BA, Korecki CL, Purmessur D, et al. Complex loading affects intervertebral disc mechanics and biology. Osteoarthritis Cartilage 2011; 19:1011-8.

15. Le Maitre CL, Pockert A, Buttle DJ, et al. Matrix synthesis and degradation in human intervertebral disc degeneration. Biochem Soc Trans 2007; 35:652-5.

16. Fujita K, Ando T, Ohba T, et al. Age-related expression of MCP-1 and MMP-3 in mouse intervertebral disc in relation to TWEAK and TNF- $\alpha$ stimulation. J Orthop Res 2012; 30:599-605.

17. Nemoto O, Yamagishi M, Yamada H, et al. Matrix metalloproteinase-3 production by

18. Tortorella MD, Pratta M, Liu RQ, et al. Sites of aggrecan cleavage by recombinant human aggrecanase-1 (ADAMTS-4). J Biol Chem 2000; 275:18566-73.

19. Hatano E, Fujita T, Ueda Y, et al. Expression of ADAMTS-4 (aggrecanase-1) and possible involvement in regression of lumbar disc herniation. Spine (Phila Pa 1976) 2006; 31:1426-32. 
1 20. Patel KP, Sandy JD, Akeda K, et al. Aggrecanases and aggrecanase-generated fragments

2 in the human intervertebral disc at early and advanced stages of disc degeneration. Spine $3 \quad 2007 ; 32: 2596-603$.

21. Le Maitre CL, Freemont AJ, Hoyland JA. Localization of degradative enzymes and their inhibitors in the degenerate human intervertebral disc. J Pathol 2004; 204:47-54.

22. Tiaden AN, Klawitter M, Lux V, et al. A detrimental role for human high temperature requirement serine protease A1 (HTRA1) in the pathogenesis of intervertebral disc (IVD) degeneration. J Biol Chem 2012; 287:21335-45.

23. Yao NZ, Zhang ZM, Jin DD. In vivo experimental study of lumbar nucleus replacement with pectin/polyvinyl alcohol composite hydrogel. Zhonghua Wai Ke Za Zhi 2010; 48:7847.

24. Chen YC, Su WY, Yang SH, et al. In situ forming hydrogels composed of oxidized high molecular weight hyaluronic acid and gelatin for nucleus pulposus regeneration. Acta Biomater 2012; 9:5181-93.

25. Mauth C, Bono E, Haas S, et al. Cell-seeded polyurethane-fibrin structures--a possible system for intervertebral disc regeneration. Eur Cell Mater 2009; 18:27-38; discussion 389.

26. Chan SC, Gantenbein-Ritter B. Intervertebral disc regeneration or repair with biomaterials and stem cell therapy--feasible or fiction? Swiss Med Wkly 2012; 142:w13598.

27. Ehlicke F, Freimark D, Heil B, et al. Intervertebral disc regeneration: Influence of growth factors on differentiation of human mesenchymal stem cells (hMSC). Int J Artif Organs 2010; 33:244-52.

28. Roberts S, Menage J, Sivan S, et al. Bovine explant model of degeneration of the intervertebral disc. BMC Musculoskelet Disord 2008; 9:24. 
1

2

3

4

5

6

7

8

9

10

11

\section{L}
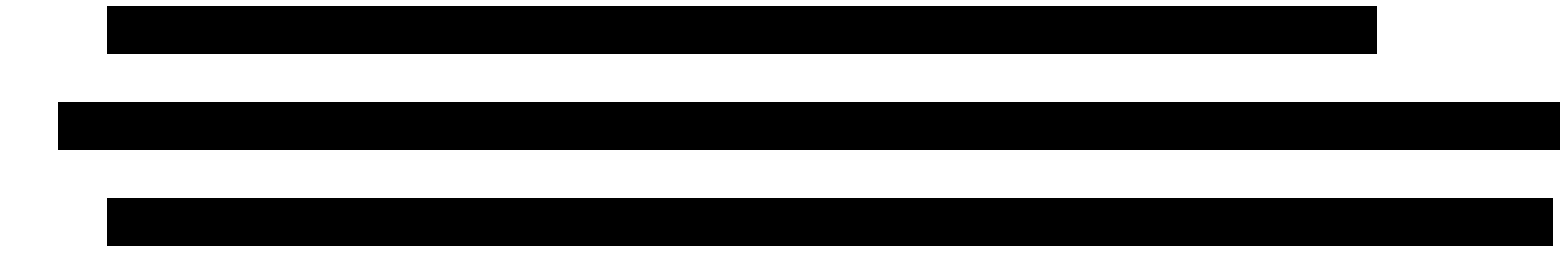

列

(
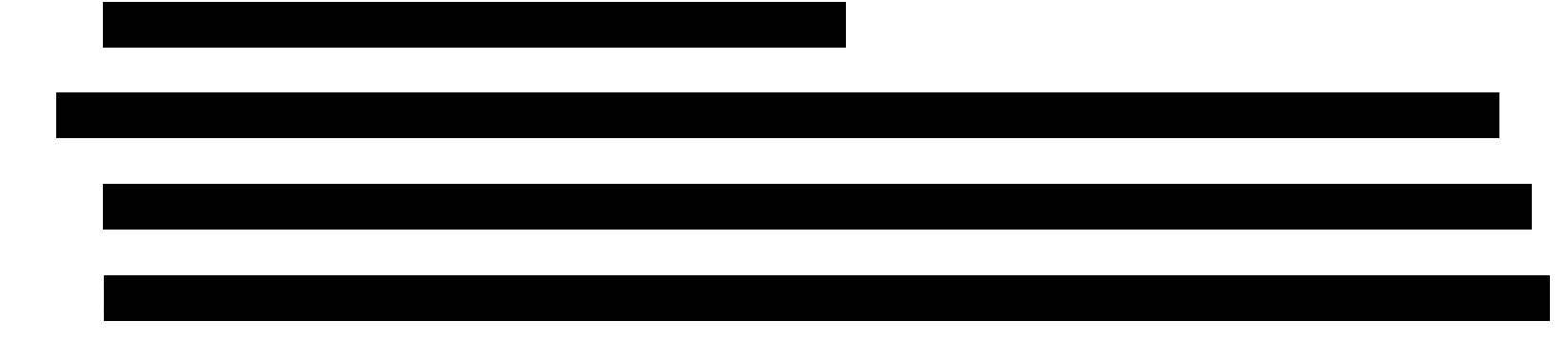

11

33. Ishiguro N, Ito T, Ito H, et al. Relationship of matrix metalloproteinases and their

3 inhibitors to cartilage proteoglycan and collagen turnover: analyses of synovial fluid from patients with osteoarthritis. Arthritis Rheum 1999; 42:129-36.

34. Zha Y, Chen Y, Xu F, et al. Elevated level of ADAMTS4 in plasma and peripheral monocytes from patients with acute coronary syndrome. Clin Res Cardiol 2010; 99:781-6.

17

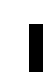

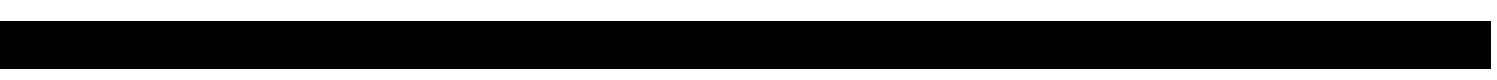

36. Bancroft JD, Stevens A, Turner DR. Theory and practice of histological techniques, Churchill Livingstone Edinburgh, 1982.

\section{Horn F. Biochemie des Menschen: das Lehrbuch für das Medizinstudium: 1200} Abbildungen, Georg Thieme Verlag, 2009.

38. Korecki CL, MacLean JJ, Iatridis JC. Dynamic compression effects on intervertebral disc 4 mechanics and biology. Spine (Phila Pa 1976) 2008; 33:1403-9. 
39. Korecki CL, Kuo CK, Tuan RS, et al. Intervertebral disc cell response to dynamic compression is age and frequency dependent. J Orthop Res 2009; 27:800-6.

40. Stokes IA, Iatridis JC. Mechanical conditions that accelerate intervertebral disc degeneration: overload versus immobilization. Spine 2004; 29:2724-32.

41. Wilke HJ, Neef P, Caimi M, et al. New in vivo measurements of pressures in the intervertebral disc in daily life. Spine (Phila Pa 1976) 1999; 24:755-62.

42. Le Maitre CL, Fotheringham AP, Freemont AJ, et al. Development of an in vitro model to test the efficacy of novel therapies for IVD degeneration. J Tissue Eng Regen Med 2009; 3:461-9.

43. Mwale F, Demers CN, Michalek AJ, et al. Evaluation of quantitative magnetic resonance imaging, biochemical and mechanical properties of trypsin-treated intervertebral discs under physiological compression loading. J Magn Reson Imaging 2008; 27:563-73.

44. Korecki CL, MacLean JJ, Iatridis JC. Characterization of an in vitro intervertebral disc organ culture system. Eur Spine J 2007; 16:1029-37.

45. Demers CN, Antoniou J, Mwale F. Value and limitations of using the bovine tail as a model for the human lumbar spine Spine 2004; 29:2793-9.

46. Haschtmann D, Stoyanov JV, Ettinger L, et al. Establishment of a novel intervertebral disc/endplate culture model: analysis of an ex vivo in vitro whole-organ rabbit culture system. Spine 2006; 31:2918-25.

47. Showalter BL, Beckstein JC, Martin JT, et al. Comparison of Animal Discs Used in Disc Research to Human Lumbar Disc: Torsion Mechanics and Collagen Content. Spine (Phila Pa 1976) 2012; 37:E900-7.

48. Holm S, Nachemson A. Variations in the nutrition of the canine intervertebral disc induced by motion. Spine (Phila Pa 1976) 1983; 8:866-74. 
49. Beckstein JC, Sen S, Schaer TP, et al. Comparison of animal discs used in disc research to human lumbar disc: axial compression mechanics and glycosaminoglycan content. Spine (Phila Pa 1976) 2008; 33:E166-73.

50. Oshima H, Ishihara H, Urban JP, et al. The use of coccygeal discs to study intervertebral disc metabolism. J Orthop Res 1993; 11:332-8.

51. Handa T, Ishihara H, Ohshima H, et al. Effects of hydrostatic pressure on matrix synthesis and matrix metalloproteinase production in the human lumbar intervertebral disc. Spine (Phila Pa 1976) 1997; 22:1085-91.

52. Minogue BM, Richardson SM, Zeef LA, et al. Transcriptional profiling of bovine intervertebral disc cells: implications for identification of normal and degenerate human intervertebral disc cell phenotypes. Arthritis Res Ther 2010; 12:R22.

53. Jim B, Steffen T, Moir J, et al. Development of an intact intervertebral disc organ culture system in which degeneration can be induced as a prelude to studying repair potential. Eur Spine J 2011; 20:1244-54.

54. Nagase H, Woessner JF. Matrix metalloproteinases The Journal of Biological Chemistry $1999 ; 274: 21491-21494$.

55. Visse R, Nagase H. Matrix metalloproteinases and tissue inhibitors of metalloproteinases: structure, function, and biochemistry. Circ Res 2003; 92:827-39.

56. Hiller O, Lichte A, Oberpichler A, et al. Matrix metalloproteinases collagenase-2, macrophage elastase, collagenase-3, and membrane type 1-matrix metalloproteinase impair clotting by degradation of fibrinogen and factor XII. J Biol Chem 2000; 275:33008-13.

57. Van Wart HE, Birkedal-Hansen H. The cysteine switch: a principle of regulation of metalloproteinase activity with potential applicability to the entire matrix metalloproteinase gene family. Proc Natl Acad Sci U S A 1990; 87:5578-82.

58. Parks WC, Mecham RP. Matrix metalloproteinases, Academic Press New York:, 1998. 
1 59. Gendron C, Kashiwagi M, Lim NH, et al. Proteolytic activities of human ADAMTS-5:

2 comparative studies with ADAMTS-4. J Biol Chem 2007; 282:18294-306.

3 60. Stanton H, Melrose J, Little CB, et al. Proteoglycan degradation by the ADAMTS family

$4 \quad$ of proteinases. Biochim Biophys Acta 2011; 1812:1616-29.

5 61. Clausen T, Kaiser M, Huber R, et al. HTRA proteases: regulated proteolysis in protein

$6 \quad$ quality control. Nat Rev Mol Cell Biol 2011; 12:152-62.

7 62. Grau S, Richards PJ, Kerr B, et al. The role of human HtrA1 in arthritic disease. J Biol $8 \quad$ Chem 2006; 281:6124-9.

9 63. Tiaden AN, Breiden M, Mirsaidi A, et al. Human serine protease HTRA1 positively regulates osteogenesis of human bone marrow-derived mesenchymal stem cells and mineralization of differentiating bone-forming cells through the modulation of extracellular matrix protein. Stem Cells 2012; 30:2271-82.

64. Tiaden AN, Richards PJ. The Emerging Roles of HTRA1 in Musculoskeletal Disease. Am J Pathol 2013:182(5):1482-8

65. Millward-Sadler SJ, Costello PW, Freemont AJ, et al. Regulation of catabolic gene expression in normal and degenerate human intervertebral disc cells: implications for the pathogenesis of intervertebral disc degeneration. Arthritis Res Ther 2009; 11:R65. 
List of Tables

2 Table 1: Bovine specific primers (Bos taurus) for real time RT-PCR using the SYBR green system.

3 All PCR reactions were run in 2-step protocol $\left(95^{\circ}\right.$ for $15 \mathrm{~s}$ and $57^{\circ} \mathrm{C}$ for $\left.40 \mathrm{~s}\right)$ for 50 cycles.

\begin{tabular}{|c|c|c|c|}
\hline Gene & Common gene name & Primer for & Primer rev \\
\hline Bt_18S & Bovine reference gene & $\begin{array}{l}\text { ACG GAC AGG ATT GAC } \\
\text { AGA TTG }\end{array}$ & $\begin{array}{l}\text { CCA GAG TCT CGT TCG } \\
\text { TTA TCG }\end{array}$ \\
\hline Bt_Col1A2 & Collagen1 A2 & GCC TCG CTC ACC AAC TTC & $\begin{array}{l}\text { AGT AAC CAC TGC TCC } \\
\text { ATT CTG }\end{array}$ \\
\hline Bt_Col 2 & Collagen 2 & $\begin{array}{l}\text { CGG GTG AAC GTG GAG } \\
\text { AGA CA }\end{array}$ & $\begin{array}{l}\text { GTC CAG GGT TGC CAT } \\
\text { TGG AG }\end{array}$ \\
\hline Bt_ACAN & Aggrecan core protein & $\begin{array}{l}\text { GGC ATC GTG TTC CAT TAC } \\
\text { AG }\end{array}$ & $\begin{array}{l}\text { ACT CGT CCT TGT CTC } \\
\text { CAT AG }\end{array}$ \\
\hline Bt_IL1b & Interleukin 1 beta & AGTGCCATCCTTCTGTCA & CATTGCCTTCTCCGCTATT \\
\hline Bt_IL-6 & $\begin{array}{l}\text { Interleukin } 6 \text { (interferon, beta } \\
\text { 2) }\end{array}$ & GACTACTTCTGACCACTC & $\begin{array}{l}\text { ATTCTTCTCACATATCTCC } \\
\text { TT }\end{array}$ \\
\hline Bt_VCAN & Versican & CTGGAGAAGATTGTGTTG & GTGTAGGTGAGATGGTAA \\
\hline Bt TIMP-1 & $\begin{array}{l}\text { Tissue inhibitor of } \\
\text { metalloproteinases_1 }\end{array}$ & CAACTCCGATGTCGTCAT & $\begin{array}{l}\text { TCTCATAACGCTGGTATAA } \\
\text { GG }\end{array}$ \\
\hline Bt TIMP-2 & $\begin{array}{l}\text { Tissue inhibitor of } \\
\text { metalloproteinases_2 }\end{array}$ & TTGGAGGAAAGAAGGAGTA & CACGATGAAGTCACAGAG \\
\hline Bt TIMP-3 & $\begin{array}{l}\text { Tissue inhibitor of } \\
\text { metalloproteinases_3 }\end{array}$ & CAGCAGATAGACTCAAGGT & GACACAGACAGACACAGT \\
\hline Bt_MMP3 & Matrix metalloproteinase 3 & $\begin{array}{l}\text { CTT CCG ATT CTG CTG TTG } \\
\text { CTA TG }\end{array}$ & $\begin{array}{l}\text { ATG GTG TCT TCC TTG } \\
\text { TCC CTT G }\end{array}$ \\
\hline Bt_MMP13 & Matrix metalloproteinase 13 & $\begin{array}{l}\text { TCC TGG CTG GCT TCC TCT } \\
\text { TC }\end{array}$ & $\begin{array}{l}\text { CCT CGG ACA AGT CTT } \\
\text { CAG AAT CTC }\end{array}$ \\
\hline Bt-ADAMTS-4 & $\begin{array}{l}\text { A disintegrin and } \\
\text { metalloproteinase with } \\
\text { thrombospondin motifs- } 4\end{array}$ & $\begin{array}{l}\text { TCC TGG CTG GCT TCC TCT } \\
\text { TC }\end{array}$ & $\begin{array}{l}\text { CCT CGG ACA AGT CTT } \\
\text { CAG AAT CTC }\end{array}$ \\
\hline
\end{tabular}


1 Table 2: Recent studies using Trypsin and/or Papain for organ culture model.

\begin{tabular}{|l|l|l|l|l|}
\hline Reference & Injected Enzyme & Load & Duration & Main Results \\
\hline Jim et al. ${ }^{53}$ & $\begin{array}{l}\text { Trypsin: } 2.5 \mathrm{~g} / 50 \mu \mathrm{l} \\
\text { PBS }\end{array}$ & No & 4 weeks & 60\% Loss of proteoglycans after 7 days \\
\hline $\begin{array}{l}\text { Roberts et } \\
\text { al. }^{28}\end{array}$ & $\begin{array}{l}\text { Papain: } 20 \mathrm{mg} / \mathrm{ml} \\
\text { Trypsin: } 1,5,10,20 \\
\mathrm{mg} / \mathrm{ml}\end{array}$ & No & 2 weeks & $\begin{array}{l}\text { Discs were macro- and microscopically } \\
\text { fragmented, severe metachromasia, } \\
\text { macroscopic cavities and 20\% loss of } \\
\text { proteoglycans after 2 weeks. }\end{array}$ \\
\hline Chan et al. $^{29}$ & $\begin{array}{l}\text { Papain: } \\
3,15,30,60,150\end{array}$ & No & 10 days & $\begin{array}{l}\text { Macroscopic cavity for 30U/ml and higher } \\
\text { GAGs completely lost for 15U/ml and } \\
\text { higher (less than 10\% left in NP area), } \\
\text { drop in compressive and rotational } \\
\text { stiffness, loss of water content for 60U/ml } \\
\text { and higher }\end{array}$ \\
\hline $\begin{array}{l}\text { Mwale } \text { et } \\
\text { al. }{ }^{43}\end{array}$ & Trypsin: $5 \mathrm{mg}$ & $\begin{array}{l}\text { Yes, } \\
1 \mathrm{~Hz}, \\
16 \mathrm{~h}\end{array}$ & 16 hours & $\begin{array}{l}\text { Effect of loading was greater on MR } \\
\text { parameters and biochemical composition } \\
\text { typical for IDD } \\
\text { Trypsin had larger effect on mechanical } \\
\text { properties }\end{array}$ \\
\hline
\end{tabular}

2 
1 Figure Legends

2

3 Figure 1. Change in disc height compared to change in GAG content in NP tissue of bovine

4

5

Figure 3. Mean DNA content/ dry weight of bovine IVD organ culture with injected enzymes $($ mean $\pm \mathrm{SEM}, \mathrm{N}=5$ ) at day 0 and after 8 days of culture. Although the value for day 0 Control group in NP tissue is higher than in all cultured groups, no significant differences amongst the five groups could be found.

Figure 4. Mean GAG/DNA ratio of bovine IVD organ culture with injected enzymes (mean \pm SEM, $\mathrm{N}=5$ ) at day 0 and after 8 days of culture.

Figure 5. HO-Proline content per dry weight tissue bovine IVD organ culture with injected enzymes (mean \pm SEM, $\mathrm{N}=5$ ) at day 0 and after 8 days of culture, NP: nucleus pulposus, AF: annulus fibrosus. 
1 Figure 6. GAG / HO-Proline ratio of bovine IVD organ culture with injected enzymes (mean

$2 \pm \mathrm{SEM}, \mathrm{N}=5$ ) at day 0 and after 8 days of culture. $*=P<0.05$.

3

4 Figure 7. Relative gene expression $\left(2^{-\Delta \Delta \mathrm{Ct}}\right.$ method) in NP and AF tissue of bovine IVD organ 5 culture with injected enzymes relative to PBS control after 8 days of culture $(\mathrm{N}=5$, mean \pm 6 SEM).

7

Figure 9. 1. Overview of classification families of proteases according to Horn $(2009)^{37} 2$. General domain arrangement of vertebrate MMPs after Nagase et al. (1999) ${ }^{54}$ and Parks et al. $(1998) .^{58}$

Figure 10. Macroscopic sagittal view of bovine coccygeal IVDs cut with a guillotine-like cutter tool after 8 days of organ culture injected either with phosphate buffered saline (PBS) control or with one of three catabolic enzymes MMP-3, ADAMTS-4 and HTRA1 (concentration of $\sim 1 \mu \mathrm{g} /$ disc) compared to the cysteine-dependent proteinase papain with 30 U/disc. $^{29}$ The arrow denotes the cavity, created after $48 \mathrm{~h}$ of incubation with $30 \mathrm{U}$ of injected papain. 

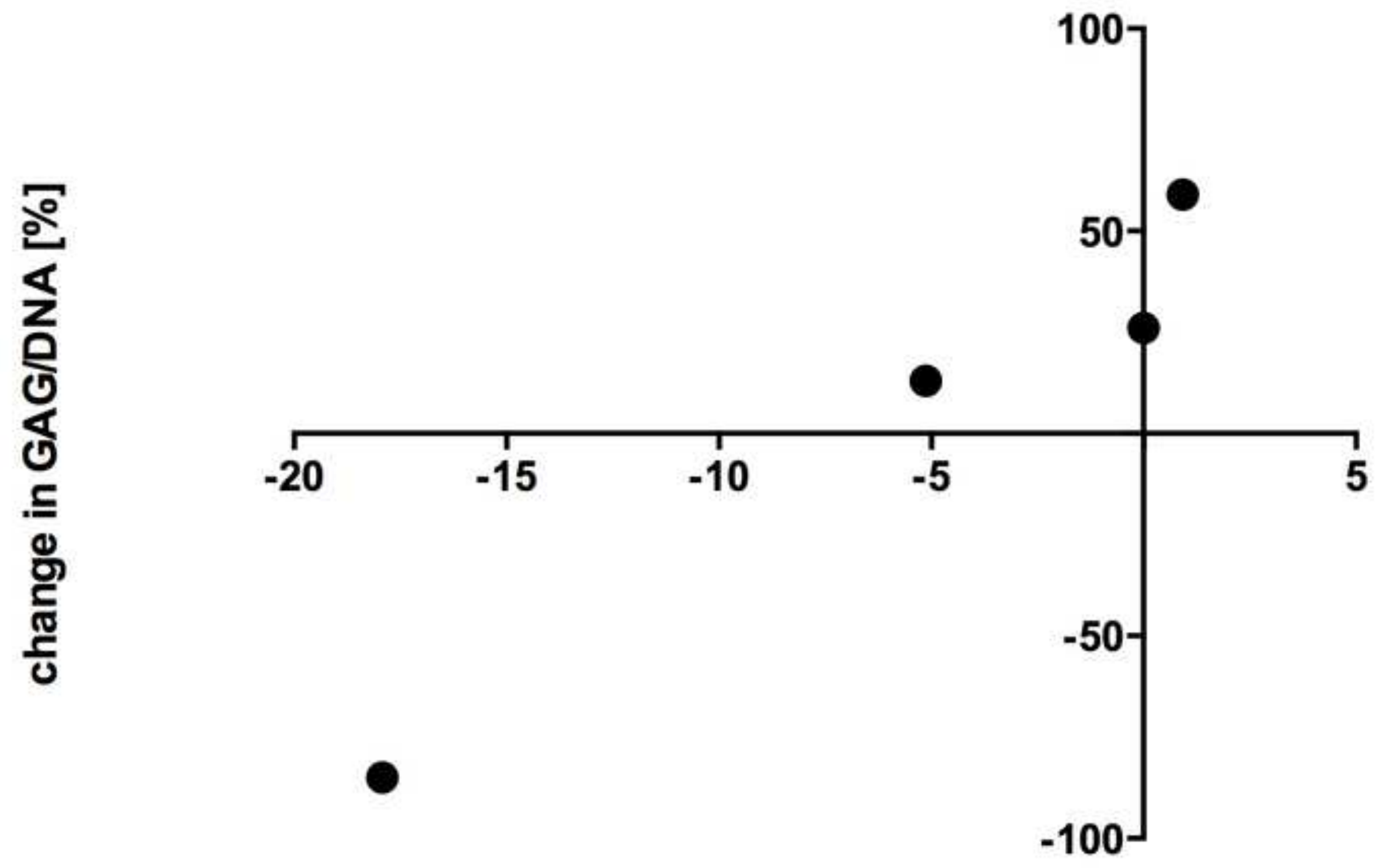

change in disc height [\%] 


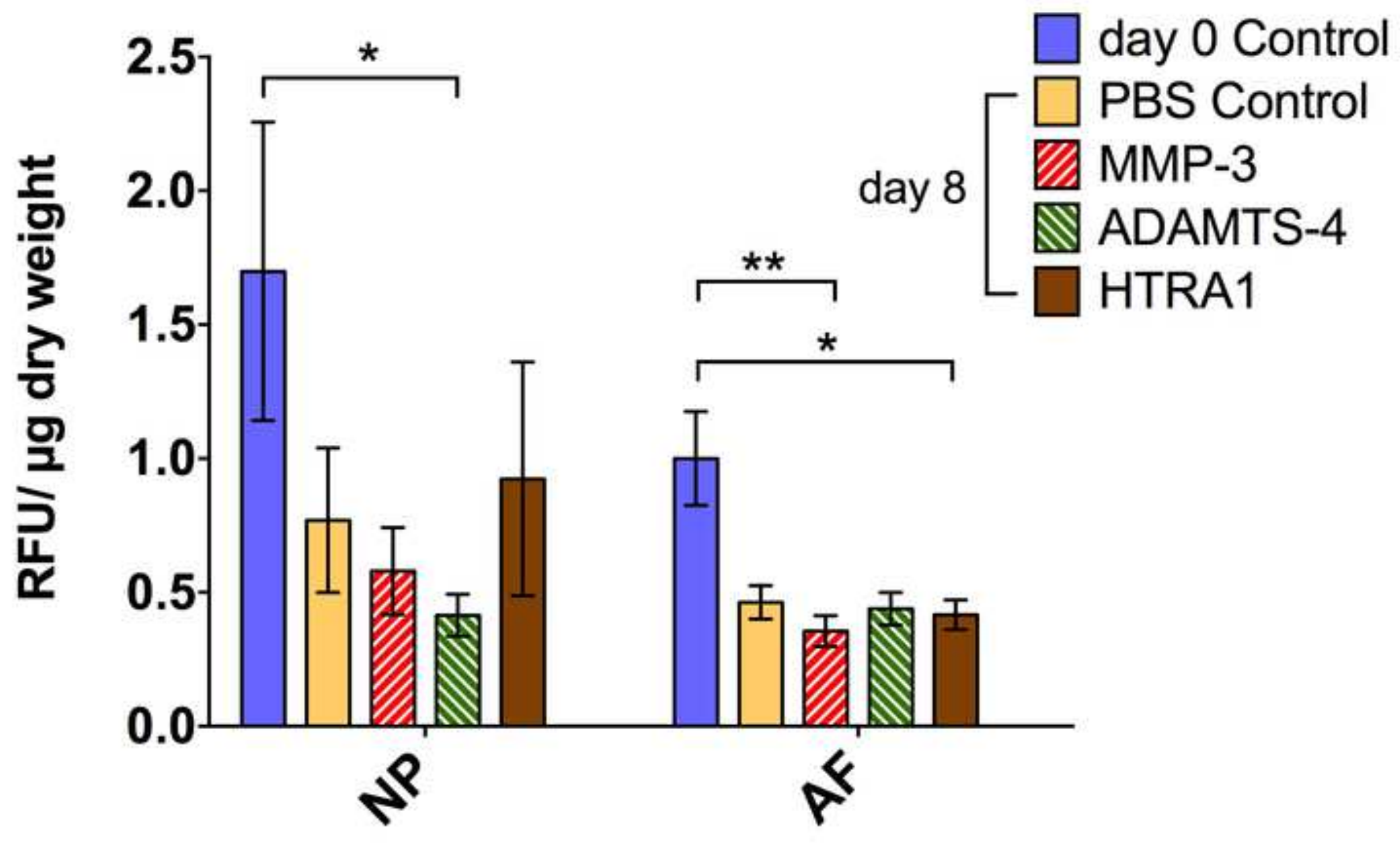




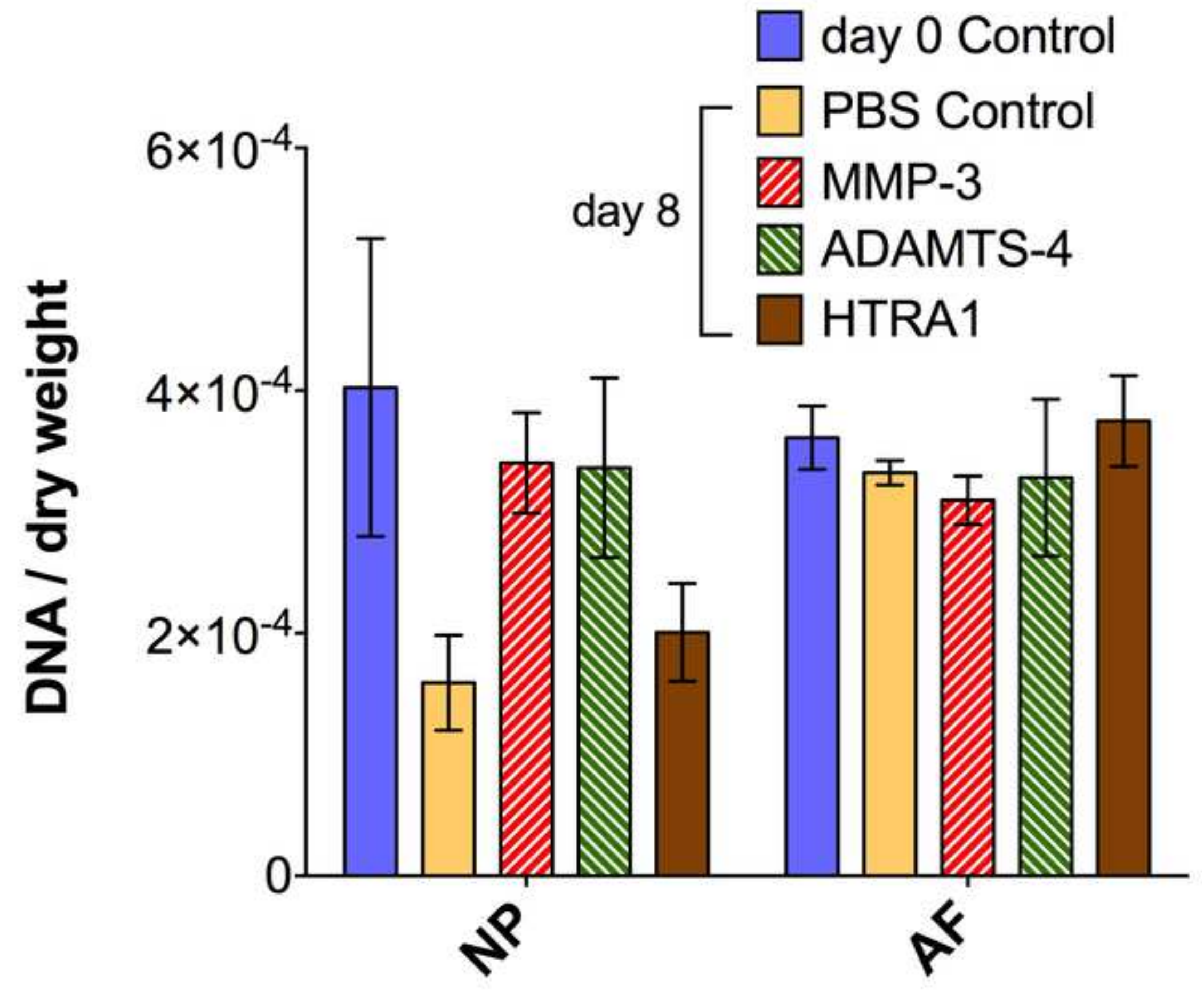




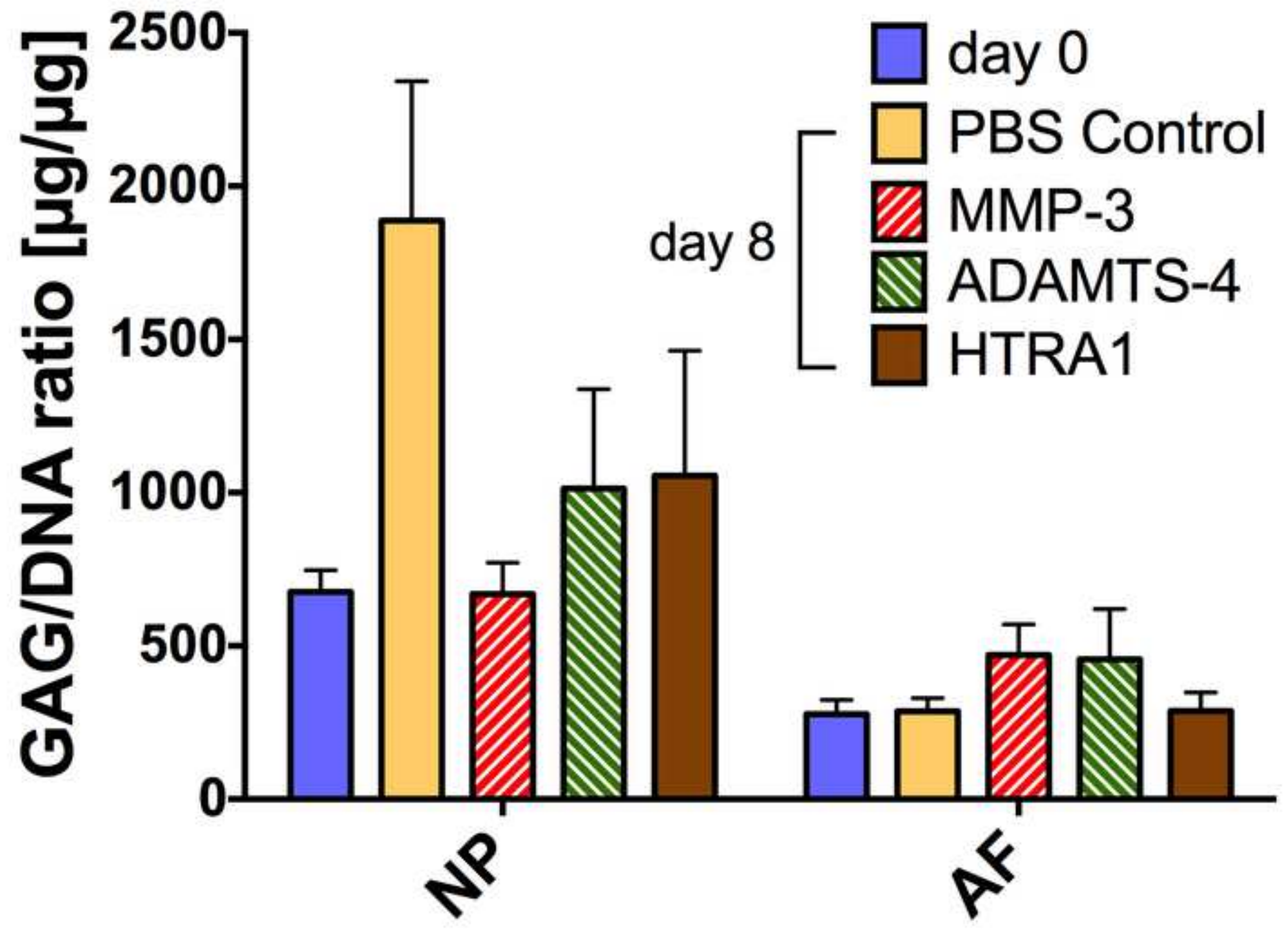




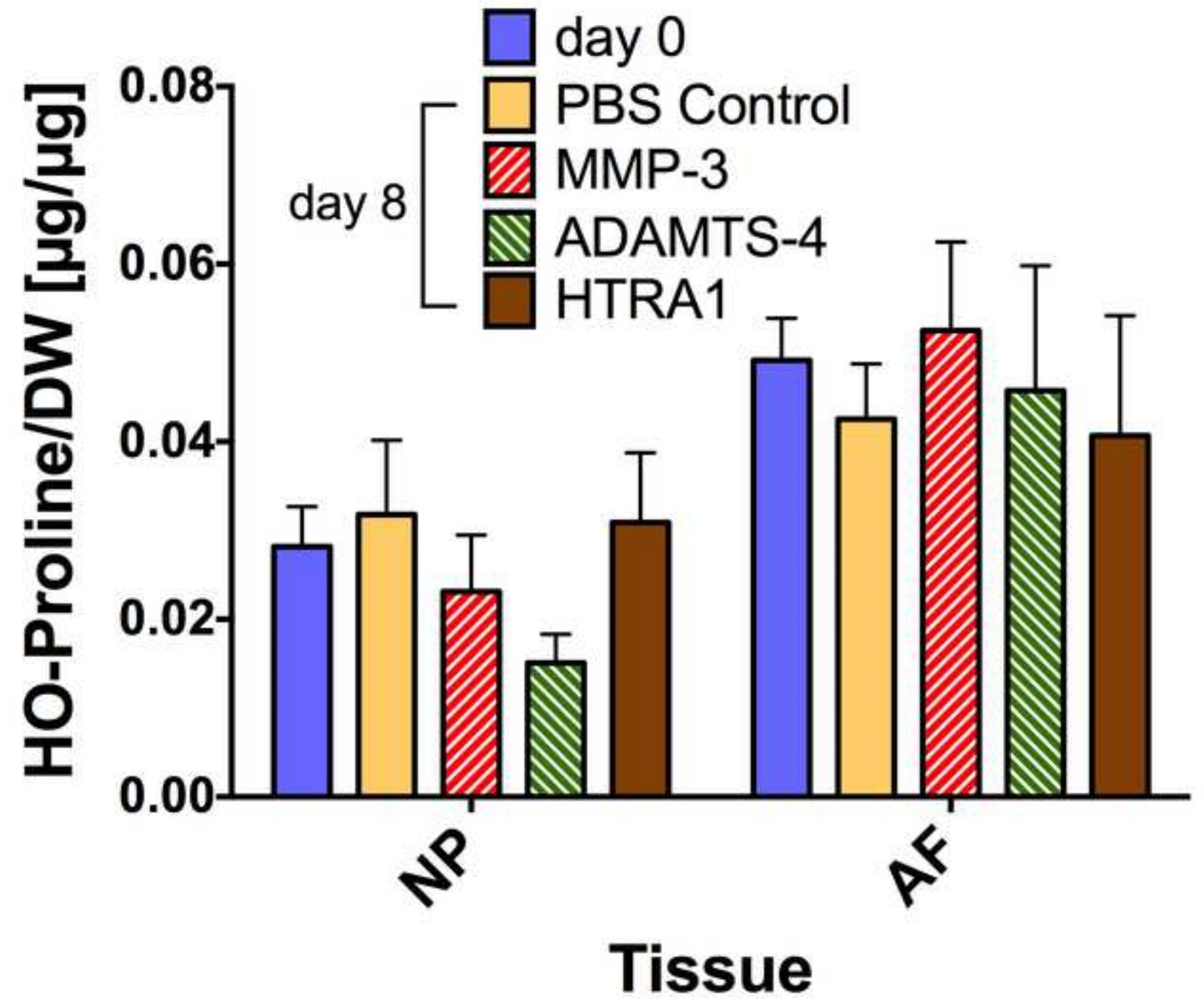




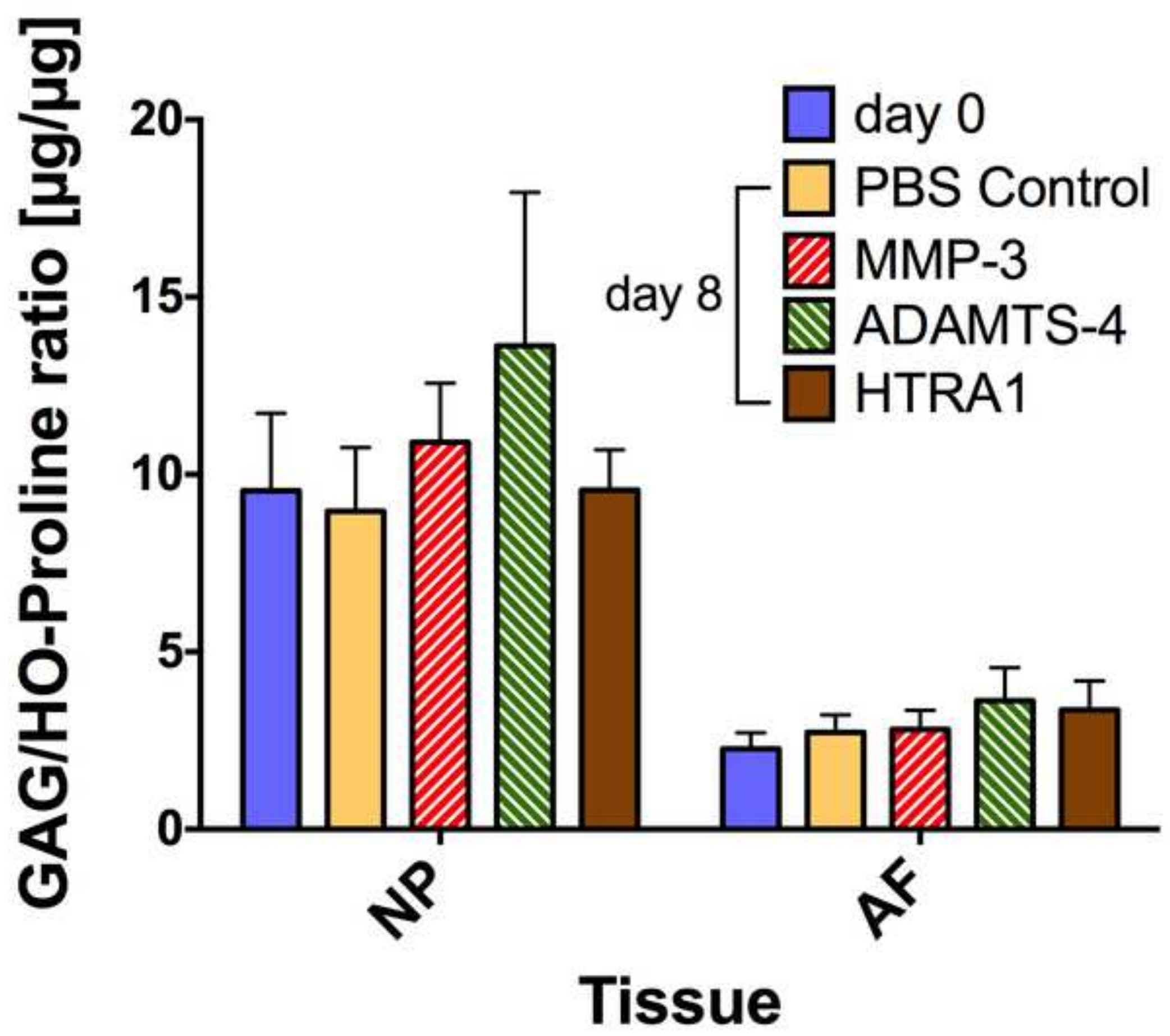



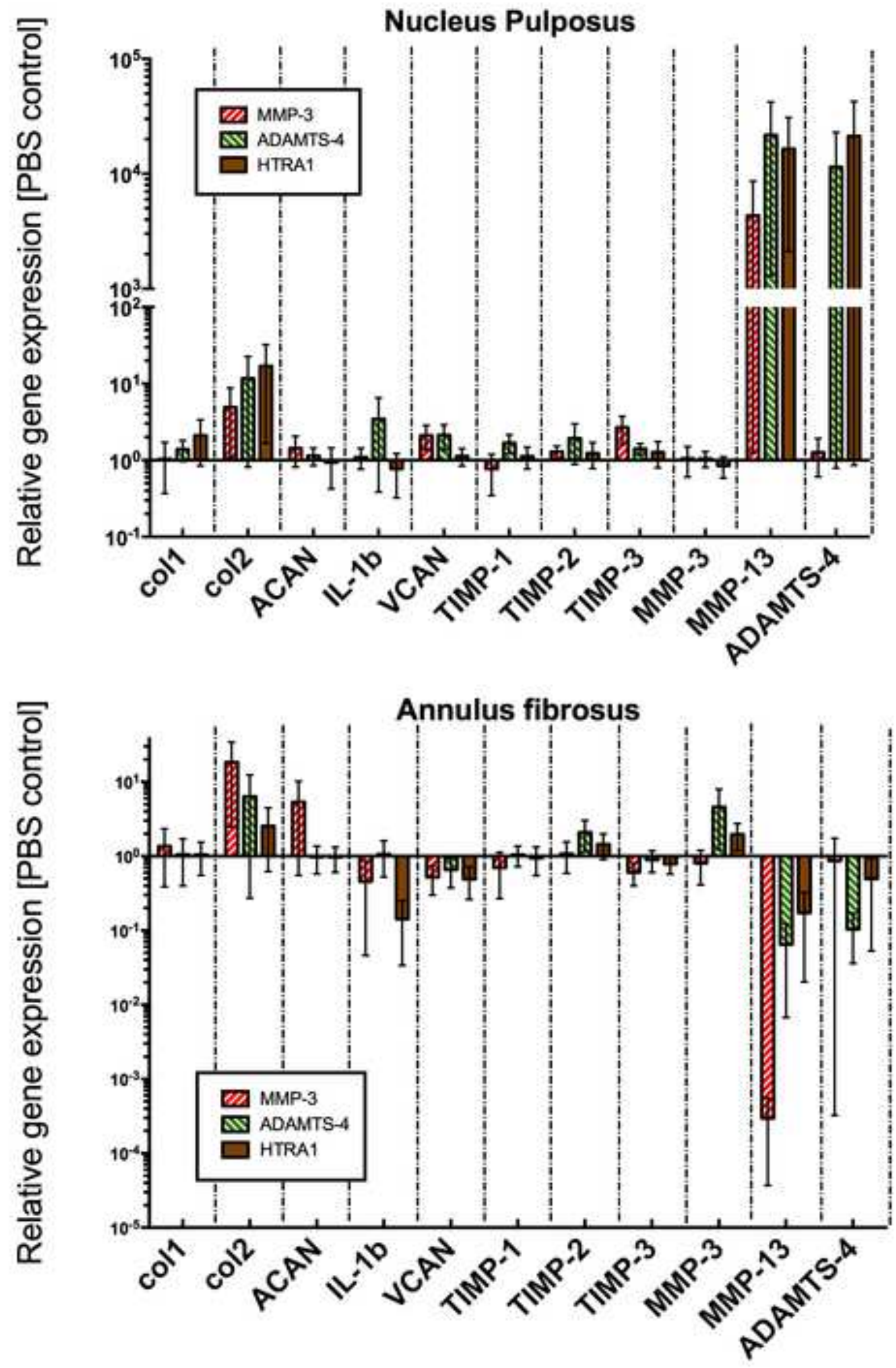
Figure 8

Click here to download high resolution image

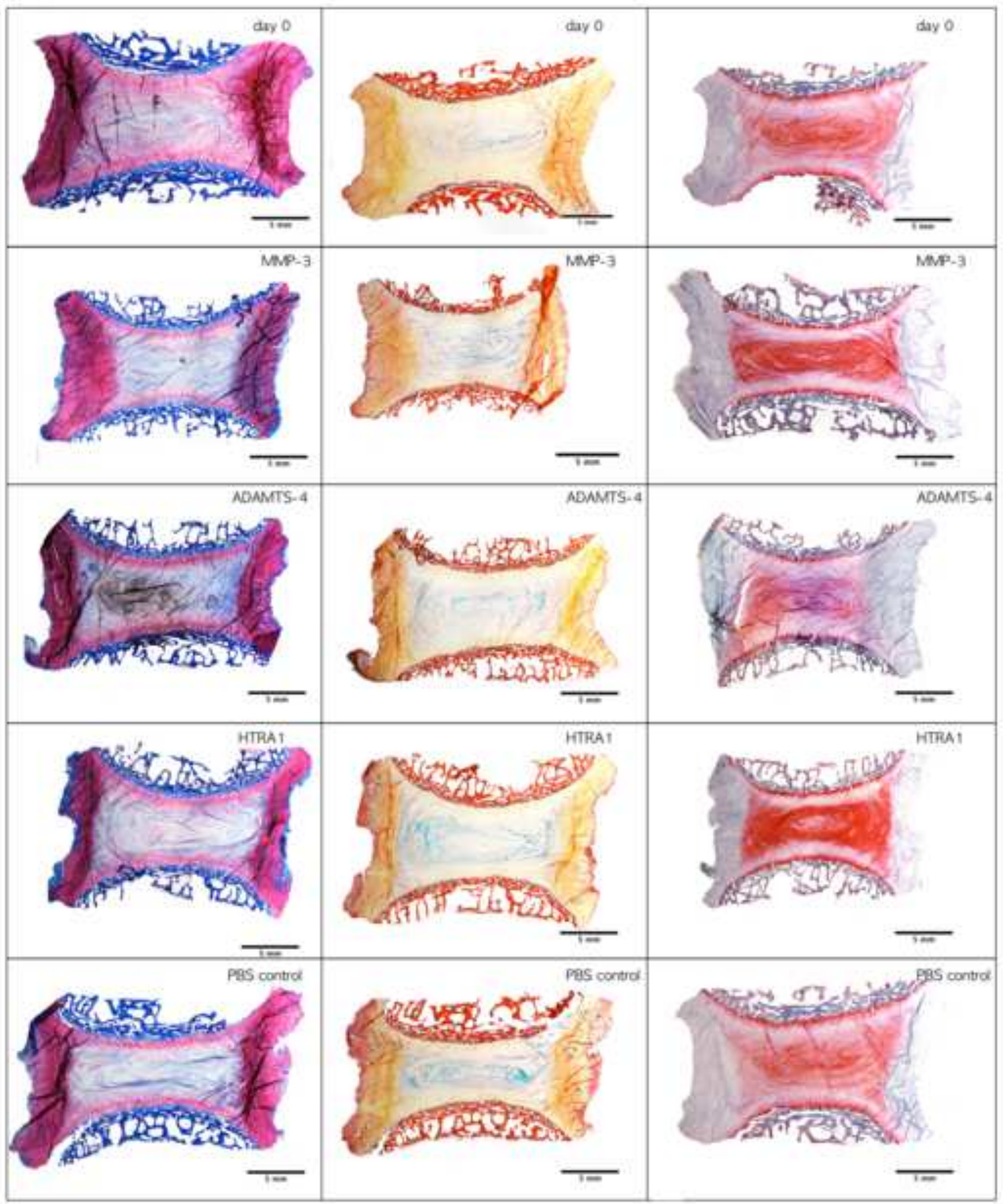


1 Overview of

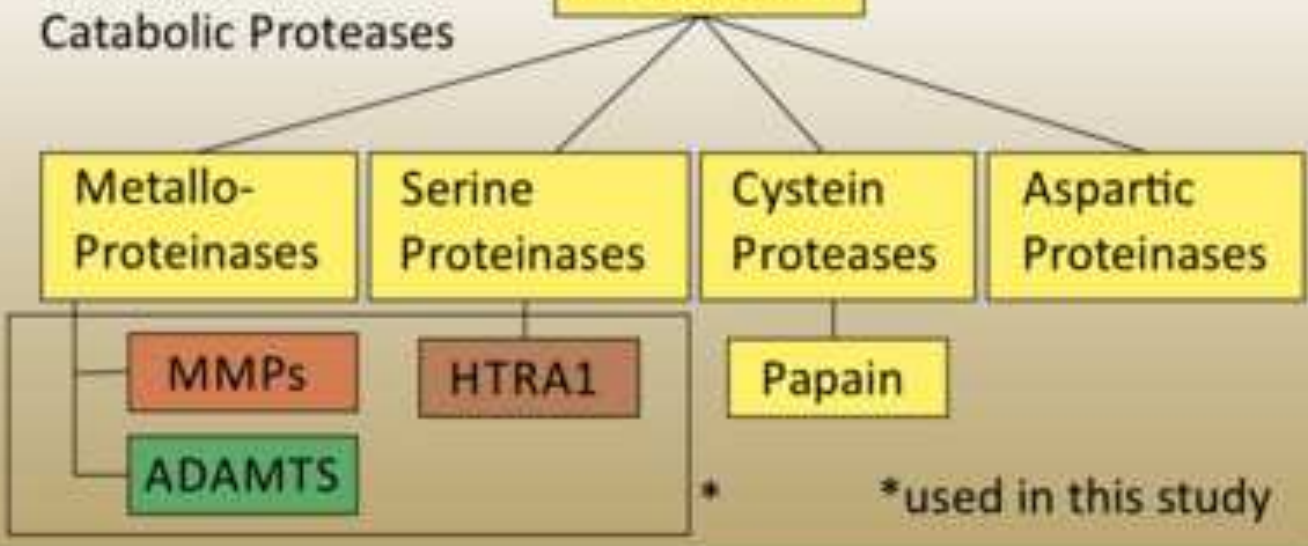

2 General arrangements of domains of the three catabolic enzyme families used in this study
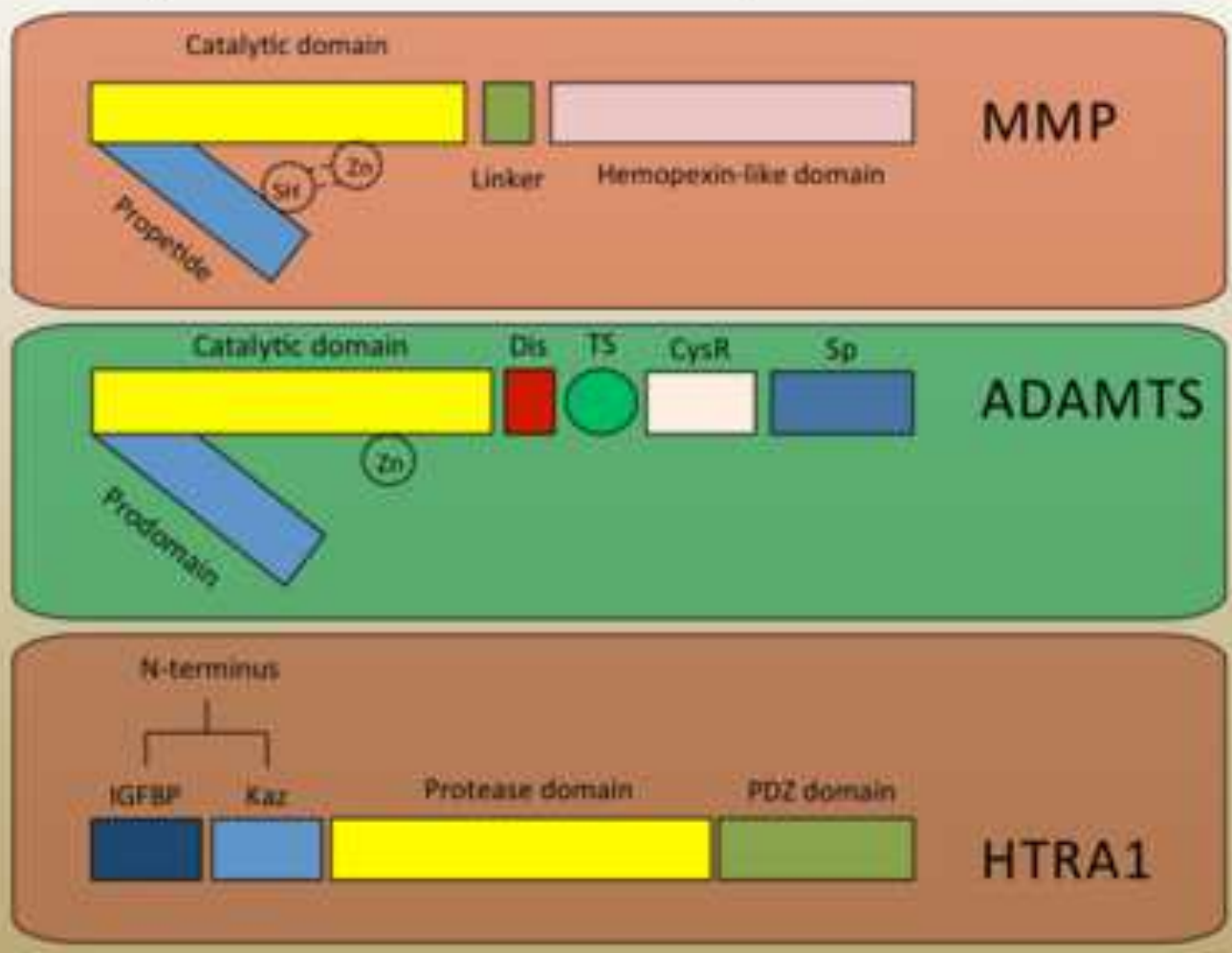

\section{Abbreviations:}

CysR: Cysteine-rich domain

Dis: disintegrin-like domain

IGFBP: Insulin-like growth factor binding protein

Kaz: Kazal-like module

PDZ: postsynaptic density of $95 \mathrm{kDa}$

SH: SulfHydrl group

Sp: $\quad$ Spacer domain

TS: thrombospondin domain

$\mathrm{Zn}: \quad$ Zinc (active site) 
Figure 10
Click here to download high resolution image

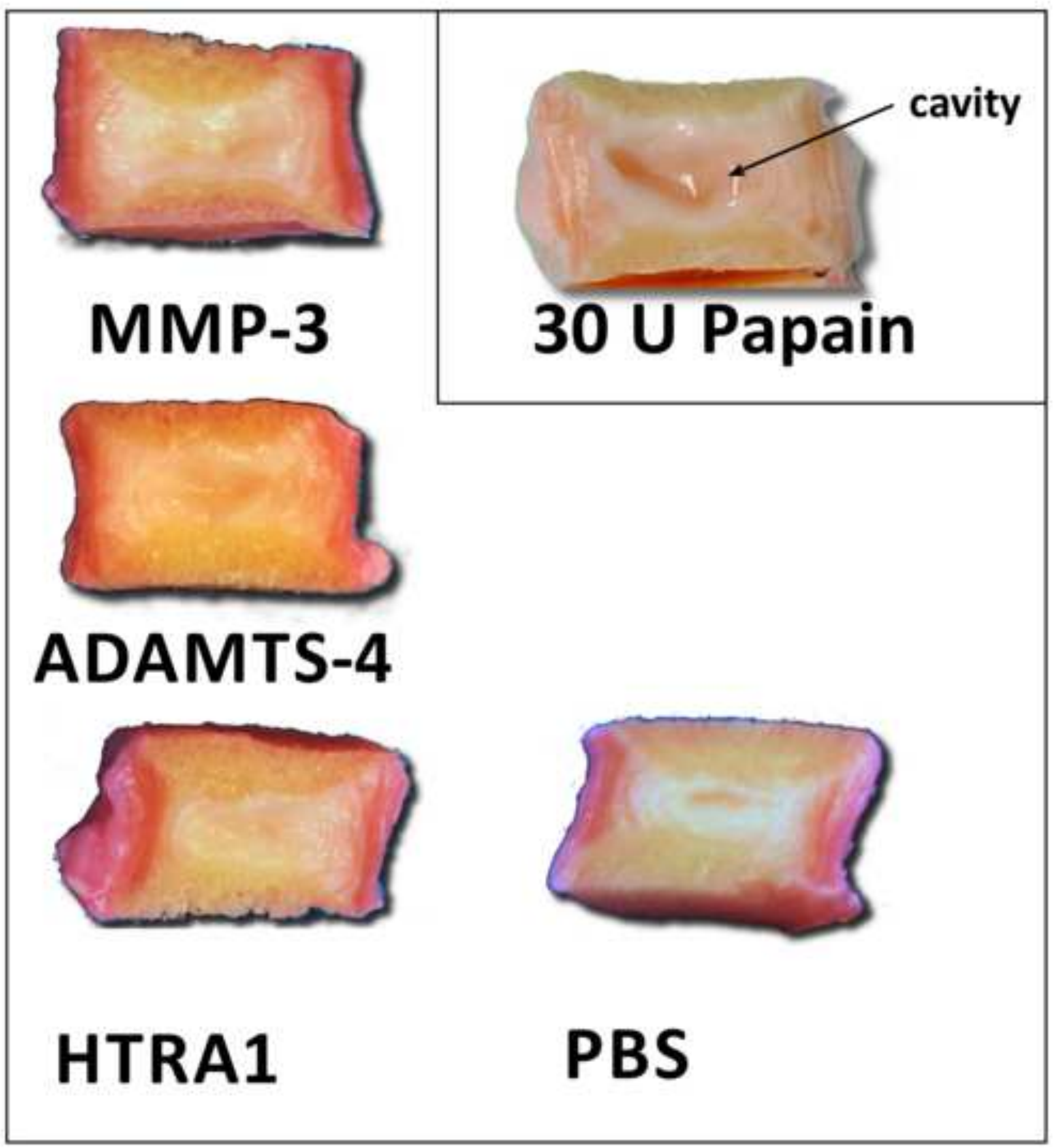

